Catlin, B. W. \& Cunningham, L. S. (1958). J. gen. Microbiol. 19, 522-539

\title{
Studies of Extracellular and Intracellular Bacterial Deoxyribonucleic Acids
}

\author{
By B. W. CATLIN and L. S. CUNNINGHAM \\ Departments of Microbiology and Anatomy, School of Medicine, Marquette \\ University, Mikwaukee, Wisconsin, U.S.A.
}

SUMMARY: Highly polymerized bacterial deoxyribonucleic acids (DNAs) obtained from extracellular and from intracellular locations were analysed. DNAs from two strains (Staphylococcus aureus and S. epidermidis) were of the type having high adenine and thymine contents; two others (Alcaligenes faecalis and Pseudomonas fluorescens) had a high content of guanine and cytosine. For each micro-organism the composition of extracellular DNA was essentially the same as that of the intracellular DNA. Conditions associated with the extracellular accumulation of DNA in cultures of 3 strains were investigated. S. aureus elaborated a deoxyribonuclease (DNase) which required calcium ion and high $\mathrm{pH}$ for activity. In a culture medium of $c . \mathrm{pH} 6$ and insufficient calcium, the DNase was inactive and DNA slime accumulated. In cultures of $\boldsymbol{P}$. fluorescens a specific ribonuclease-sensitive DNase inhibitor protected slime DNA from depolymerization by culture DNase. In cultures of $A$. faecalis, also, both a DNA slime and a low concentration of DNase may occur. This enzyme, detected by studying its action against solutions of calf thymus DNA prepared from dried fibres, was activated by various cations within the $\mathrm{pH}$ range of cultures. Unlike other DNases, however, it has little capacity to attack the slimelayer DNA, which presumably is more nearly native.

Highly polymerized deoxyribonucleic acid (DNA) may be present extracellularly in cultures of a variety of bacteria, and observable when a slimy sediment or pellicle accumulates (Smithies \& Gibbons, 1955; Catlin, 1956). The polymerized DNA commonly remains associated with the gel-like slime, rather than going into solution in the culture fluid as would be expected of uncomplexed DNA. Elastic recoil may be observed by rotating the sediment into a spiral, which gradually unwinds under its own impetus. Microscopic examination of a wet mount quickly prepared from coiled slime shows twitching streamers of organisms embedded in a relatively transparent matrix.

Polymerized extracellular DNA may be detected even in 6-12 hr. broth cultures by centrifugation and study of the slimy organisms. The origin of this DNA is not obvious, since normal young cultures are not suspected usually of having any significant proportion of lysing organisms. In view of the great differences that may be found between DNAs of various bacterial species (Lee, Wahl \& Barbu, 1956), it was thought that a difference in the mechanism of formation of intracellular and extracellular DNAs might be revealed by differences in their base composition. Instead, a striking similarity was found in the proportions of bases composing the DNAs isolated from extracellular and from intracellular locations.

When DNA is responsible for the character of a slime, its viscosity and capacity to form a web-like fibrous precipitate in ethanol are rapidly decreased 
by low concentrations of crystalline deoxyribonuclease (DNase) that are without effect on the viability of the organisms. An active bacterial DNase released extracellularly by intact organisms or liberated by lysis, likewise, will depolymerize extracellular DNA. Thus, the absence of slime accumulation does not necessarily indicate absence of production of such DNA.

DNases have been found in the organisms or culture fluids of a number of bacteria, including Streptococcus pneumoniae (McCarty \& Avery, 1946), S. pyogenes (McCarty, 1948) Staphylococcus aureus (Cunningham, Catlin \& Privat de Garilhe, 1956), Escherichia coli (Cohen, 1947), Serratia marcescens (Zamenhof, Brawerman \& Chargaff, 1952), Salmonella typhi (Kay, 1954), Shigella flexneri (Masui et al. 1956), Pseudomonas fluorescens (Catlin, 1956), Brucella suis and B. abortus (Mauzy, Braun \& Whallon, 1955), four species of Clostridium (Oakley \& Warrack, 1951; Warrack, Bidwell \& Oakley, 1951), Bacillus subtilis and Mycobacterium avium (Masui et al. 1956). In addition, DNase action has been detected (unpublished survey) in cultures of many other representatives of Enterobacteriaceae (most strains of Salmonella, Ballerup strain of E. freundii, Providencia, Proteus), in Vibrio metchnilcovi, B. anthracis, and in a non-pathogenic Mycobacterium.

In cultures of Staphylococcus aureus, activity of the extracellular DNase generally prevents accumulation of DNA slime. Certain culture conditions, however, decrease DNase activity sufficiently to allow polymerized DNA to accumulate. Clearly, the generality of occurrence of either extracellular DNA or DNase cannot be determined merely on the basis of presence or absence of DNA slime. Investigations are required of the properties of DNases and conditions associated with accumulation of extracellular DNA. Results of experiments with three unrelated strains are presented in this paper.

\section{METHODS}

Materials. Dehydrated culture media (brain +heart infusion and heart infusion broth), proteose-peptone, yeast extract, and agar were obtained from Difco Laboratories, Inc., Detroit, Michigan. Pancreatic DNase (once crystalized), pancreatic ribonuclease (crystalline, salt free) and lysozyme (twice crystallized) were obtained from Worthington Biochemical Corporation, Freehold, N.J.

\section{Analytical methods}

DNase activity was measured by a previously described viscometric method (Cunningham et al. 1956). Results are expressed as before, except that a unit has been adopted, for convenience, one-eighth as large as that used previously.

Deoxyribose (or DNA) was determined by the diphenylamine reaction (Dische, 1955). Pentose was determined by the method of Webb (1956), and values were expressed as ribonucleic acid (RNA). Phosphorus was determined by the method of King (1932), or preferably (because of the explosive properties of perchloric acid), by that of Fiske \& Subbarow (1925). Samples of DNA were dried to constant weight at $70^{\circ}$ before determination of phosphorus content. Spectrophotometric measurements (in a Beckman Model 
DU spectrophotometer) were carried out on DNA dissolved in $0 \cdot 1 \mathrm{M}-\mathrm{NaCl}$ (Chargaff, 1955).

Before base analyses, ribonucleic acid was in some cases (Table 1) removed by treatment with alkali (Smith \& Wyatt, 1951). DNA samples were sealed in tubes with formic acid and a minimum volume of air (Wyatt \& Cohen,

Table 1. Purine and pyrimidine contents of deoxyribonucleic acid preparations

Source of DNA
Staphylococcus aureus
Strain SA-B
Extracellular-1*
Extracellular-2*
Intracellular *
Strain 209 P (whole cells) $\dagger$
Staphylococcus epidermidis
Extracellular*
Intracellular $\dagger$
Pseudomonas fluorescens
Strain B/S
Extracellular $\ddagger$
Intracellular $\$$
Alcaligenes faecalis
Extracellular $\dagger$
Intracellular*

\begin{tabular}{|c|c|c|c|}
\hline Guanine & Cytosine & Adenine & Thymine \\
\hline $20 \cdot 2$ & $19 \cdot 1$ & $32 \cdot 0$ & $28 \cdot 7$ \\
\hline $19 \cdot 0$ & $19 \cdot 3$ & $33 \cdot 8$ & $28 \cdot 0$ \\
\hline $21 \cdot 0$ & $19 \cdot 0$ & $30 \cdot 8$ & $29 \cdot 2$ \\
\hline $18 \cdot 5$ & $19 \cdot 2$ & $31 \cdot 0$ & $31 \cdot 2$ \\
\hline $18 \cdot 5$ & $17 \cdot 5$ & $31 \cdot 7$ & $32 \cdot 2$ \\
\hline 17.5 & $17 \cdot 6$ & $31 \cdot 0$ & $33 \cdot 9$ \\
\hline $\mathbf{3 4} \cdot \mathbf{3}$ & $30 \cdot 4$ & $17 \cdot 8$ & $17 \cdot 7$ \\
\hline $33 \cdot 0$ & $30 \cdot 8$ & $17 \cdot 3$ & $19 \cdot 0$ \\
\hline 31.5 & $37 \cdot 6$ & $14 \cdot 0$ & $16 \cdot 7$ \\
\hline $31 \cdot 8$ & $\mathbf{3 6} \cdot \mathbf{0}$ & 15.9 & $16 \cdot 2$ \\
\hline
\end{tabular}

* Purification by method described, steps 1-5.

$\dagger$ Alkali-treated.

+ Ribonuclease-treated.

1953) and heated, within metal shields, in an oil bath (Dow-Corning 550 Fluid) at $170-175^{\circ}$ for $75 \mathrm{~min}$. The bases released were determined according to Wyatt (1951), except that the chromatograms were developed in butanol+ water + ammonia (Hotchkiss, 1948), and recently published optical values were used (Johnson, 1955; Shugar \& Fox, 1952) which, however, differ very little from those of Wyatt.

\section{Bacterial deoxyribonucleases}

Slightly purified DNases were prepared from Alcaligenes faecalis and from Pseudomonas fluorescens by the same general method. Brain theart infusion (litre quantities in Fernbach flasks) was inoculated with a suspension of organisms from 18-20 hr. infusion agar cultures and was incubated at about $25^{\circ}$ with agitation for 5-18 hr. Cultures were harvested by centrifugation and the pooled slimy sediments were washed once or twice in $0 \cdot 1 \mathrm{M}$-tris [hydroxymethyl] aminomethane (Sigma Chem. Co.) buffer, pH 7.5, with 0.07 $\mathrm{M}-\mathrm{NaCl}$ ). The organisms were resuspended in this buffer to make a final concentration 25-100 times that in the original culture and were disintegrated by $15 \mathrm{~min}$. exposure in a $10 \mathrm{kc}$. Raytheon sonic oscillator. Large amounts of nucleic acids and other impurities were present in the supernatant fluids after centrifuga- 
tion at $32,700 \mathrm{~g}$ for $1 \mathrm{hr}$. at $3^{\circ}$ in a Servall superspeed refrigerated centrifuge. Precipitation in the presence of $\mathrm{MnCl}_{2}$ (Korkes, del Campillo, Gunsalus \& Ochoa, 1951) removed some impurities, together with some of the DNase activity. Precipitates were formed first at $\mathrm{pH} 6$ by addition of $\mathrm{HCl}$, second at pH 8.5 with added $\mathrm{NaOH}$, and lastly at about $\mathrm{pH} 6.8$. Each of the fairly massive precipitates was removed by centrifugation in the cold. In the case of $P$. fuorescens, a considerable amount of the activity removed with the first acid precipitate could be extracted with $0 \cdot 14 \mathrm{M}-\mathrm{NaCl}$ solution. The supernatant fluid from the last centrifugation was dialysed overnight in the cold against 2 l. neutralized 0.001 M-(ethylenedinitrilo)-tetraacetic acid, Eastman (EDTA). Further dialysis was carried out for $24 \mathrm{hr}$. against six to eight changes of demineralized water or $\mathrm{NaCl}$ solution $(0.5 \%$, w/v). The fluid after centrifugation was lyophilized to dryness. The resulting fluffy buff-coloured material (2-10 units/mg.) was readily soluble ( $A$.faecalis) or moderately soluble (P. fluorescens) in distilled water.

\section{DNA preparations}

Highly purified calf thymus DNA (prepared by the method of Kay, Simmons \& Dounce, 1952) was used as reference DNA. Aqueous solutions prepared from the dried fibres were used as control in all viscometric tests of DNase activity. Non-bacterial DNA prepared by a method comparable to that used for bacterial DNA was needed as control in some tests. For this purpose, the spleen of a dog was obtained under anaesthesia and immediately homogenized in cold $\mathbf{0 . 4 1} \%(\mathrm{w} / \mathrm{v})$ sodium dodecyl sulphate solution by means of a Waring blendor. Nucleic acid fibres were obtained by the addition of 2 vol. of ethanol. In a similar manner, crude DNA was obtained from thymus tissue of a freshly slaughtered calf. Purification in both cases was carried out as described for bacterial DNA.

The general method for obtaining the extracellular and intracellular preparations of bacterial DNA and the steps of purification are illustrated by the procedure used with Staphylococcus aureus, strain SA-B. Cultures in brain + heart infusion with $4 \%(\mathrm{w} / \mathrm{v})$ added $\mathrm{NaCl}$ were incubated at $36^{\circ}$ for $38 \mathrm{hr}$. The organisms were harvested by centrifugation $(1150 \mathrm{~g})$ and were resuspended in a volume of broth equal to one-thirtieth the volume of the discarded supernatant. $\mathrm{NaCl}$ was used in $S$. aureus cultures to inhibit the extracellular DNase but was not used in cultures of the other bacteria. After the latter were harvested, the organisms were resuspended in a solution containing $\mathrm{NaCl}(0.14 \mathrm{M})$ and sodium citrate $(0.015 \mathrm{M} ; \mathrm{pH} \mathrm{7.4} ;$; 'standard buffer' of Zamenhof, Alexander \& Leidy, 1953). The suspension of slimy bacterial sediments was stirred mechanically for $10 \mathrm{~min}$. to obtain a homogeneous mixture. This was divided into two portions.

To obtain extracellular DNA stock sodium dodecyl sulphate (Kay et al. 1952) was slowly added to one portion of organisms to give a concentration of $0.2 \%(w / v)$. The mixture was stirred mechanically at room temperature for $2 \mathrm{hr}$. After this time, with the bacteria which had been suspended in 'standard buffer', solid $\mathrm{NaCl}$ was slowly added to give a final concentration 
of $0.5 \mathrm{M}$ and stirring was continued for an additional $10 \mathrm{~min}$. The mixture was centrifuged $\left(32,700 \mathrm{~g} ; 1 \mathrm{hr} . ; 3^{\circ}\right)$ and the sedimented organisms were discarded. The beaker into which the supernatant fluid had been decanted was vigorously rotated by hand in a horizontal plane while $2 \mathrm{vol}$. of ethanol were slowly added. This ideally resulted in the formation of a single mass of fibres, which soon could be lifted out as a whole. The fluid with its content of amorphous precipitate was poured through a fine stainless-steel wire screen to collect any small isolated fibres. The mass of fibres was drained, washed in $75 \%(\mathrm{v} / \mathrm{v})$ ethanol in water, frequently changed until the ethanolic solution was no longer milky, flattened as a sheet against the side of the beaker with a stirring rod to free the mass of excess fluid, and dissolved in $30 \mathrm{ml}$. of 'standard buffer'. This solution of crude DNA was designated extracellular-1.

The second portion of the suspension of organisms was centrifuged $(32,700 \mathrm{~g}$; $\left.1 \mathrm{hr} . ; 3^{\circ}\right)$ and the supernatant fluid decanted. From this fluid a small amount of fibrous precipitate was obtained on addition of ethanol as described above. The well-washed fibres were dissolved in 'standard buffer' and this fraction was designated extracellular-2. (Most other bacteria did not yield this fraction.) The sedimented organisms were resuspended in a solution containing $0.1 \mathrm{M}-\mathrm{NaCl}$ and $0.015 \mathrm{M}-\mathrm{MgCl}_{2}$. Remaining extracellular DNA was digested at $37^{\circ}$ with pancreatic DNase $(0.005 \mathrm{mg}$. $/ \mathrm{ml}$.). The organisms were centrifuged, washed, and resuspended in $20 \mathrm{ml}$. of a solution containing $0.1 \mathrm{M}-\mathrm{NaCl}$ and 0.1 M-EDTA, and were frozen at $-55^{\circ}$. When later thawed, the organisms were lysed by lysozyme $(0.5 \mathrm{mg} . / \mathrm{ml}$.) neutralized EDTA (final concentration $2 \mathrm{mg} . / \mathrm{ml}$.), with $\mathrm{NaOH}$ added to give final $\mathrm{pH} 7 \cdot 6$ (Repaske, 1956). After $6 \mathrm{hr}$. at $25^{\circ}$ with occasional hand stirring, the mixture was very thick and sticky. Addition of 2 vol. of ethanol gave a dense precipitate. In this case, fibres could not be lifted from the ethanolic solution without undue loss. Therefore, the material was centrifuged and the sediment was dissolved with overnight stirring in the cold in a solution containing $1.0 \mathrm{M}-\mathrm{NaCl}$ with $0.015 \mathrm{M}$-sodium citrate. The solution was centrifuged, ethanol was added to the supernatant fluid, and the resulting fibres were drained and dissolved in 'standard buffer'. This crude DNA was designated intracellular fraction.

Each of the fractions, thereafter, was carried through the same steps of purification.

(1) Stock sodium dodecyl sulphate was slowly added to give a final concentration of $0.41 \%(\mathrm{w} / \mathrm{v})$ (Kay et al. 1952). After rapid mechanical stirring for $3 \mathrm{hr}$., solid $\mathrm{NaCl}$ was added to bring the concentration to $\mathrm{M}$ and the stirring was continued for $15 \mathrm{~min}$. The solution was then centrifuged $(32,700 \mathrm{~g}$; $1 \mathrm{hr} . ; 3^{\circ}$ ) and the supernatant fluid decanted. Addition of 2 vol. of ethanol resulted in the formation of fibres, which were washed as described above, and were dissolved in $\mathrm{M}-\mathrm{NaCl}$. The sediment was re-extracted in the same way and fibres were added to those from the first extraction.

(2) A $20 \%(w / v)$ solution of cetyltrimethylammonium bromide was added to a final concentration of $2 \%$. 'Cetrimide' [Eastman technical, crystallized from $40 \%(\mathrm{w} / \mathrm{v})$ solution in $95 \%(\mathrm{v} / \mathrm{v})$ ethanol in water by storing overnight at $5^{\circ}$ ] or 'Cetavlon' [generously furnished by Imperial Chemical 
(Pharmaceuticals) Ltd., Manchester] were used with apparently similar results. The solution was stirred for $30-60 \mathrm{~min}$. and 1 vol. of distilled water was slowly added, bringing the concentration of $\mathrm{NaCl}$ to $0.5 \mathrm{~m}$ (Dutta, Jones \& Stacey, 1953). The container was rotated uniformly during addition of the water and for a moment thereafter, while a fibrous precipitate formed. The fibres were lifted (or collected by centrifugation, when necessary) and further purified by two reprecipitations from $\mathrm{M}-\mathrm{NaCl}$ solution by dilution to $0.5 \mathrm{M}$ with water.

(3) The DNA was redissolved in $\mathrm{M}-\mathrm{NaCl}$ solution with mechanical stirring at $3^{\circ}$. Step 1 was repeated.

(4) The DNA was dissolved in $0.5 \mathrm{M}-\mathrm{NaCl}$ solution and calcium chloride was added to make 0.5 м (McCarty \& Avery, 1946; Dutta et al. 1953). This was stirred for 1-2 hr. and ethanol was then slowly added to a final concentration of $20 \%(\mathrm{v} / \mathrm{v})$. Fibres formed which were lifted, drained, and washed in a solution containing $0 \cdot 14 \mathrm{M}-\mathrm{NaCl}, 0 \cdot 5 \mathrm{M}-\mathrm{CaCl}_{2}$, and $20 \%(\mathrm{v} / \mathrm{v})$ ethanol in water. The drained fibres were dissolved in $\mathrm{NaCl}(\mathrm{M})+$ citrate $(0.02 \mathrm{M})$ solution

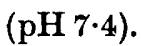

(5) Step 1 was repeated. The DNA fibres were redissolved in $\mathrm{NaCl}(0.5 \mathrm{M})+$ citrate $(0.02 \mathrm{M})$ solution $(\mathrm{pH} \mathrm{7 \cdot 4})$. The preparation was subjected to a final centrifugation $\left(32,700 \mathrm{~g} ; 90 \mathrm{~min} . ; 3^{\circ}\right)$ and to the supernatant fluid two volumes of ethanol were added. The resulting fibres were washed repeatedly in $75 \%(v / v)$ ethanol in water, drained, and dissolved in $0 \cdot 14 \mathrm{M}-\mathrm{NaCl}$ solution.

\section{RESULTS}

\section{Analyses of DNA preparations}

Staphylococcus aureus (Micrococcus pyogenes var. aureus). The coagulasepositive strain, SA-B, isolated from clinical material, was used because of the interest attached to a study of the extracellular DNA produced by a strain that also was known to produce high levels of extracellular DNase activity. Base analyses of these preparations are given in Table 1, together with values obtained for comparative purposes from alkali-treated DNA extracted from whole organisms $(20 \mathrm{hr}$. infusion agar cultures) of the well-known penicillin test strain, 209P. Other data follow.

Extracellular-1 had $7 \cdot 1 \%$ phosphorus. Optical density ratios were $250 / 260$ $(0.86), 280 / 260(0.53) ; \epsilon(\mathrm{P})$ 7000. Extracellular-2 had $6.8 \%$ phosphorus. Optical density ratios were: $250 / 260(0.86), 280 / 260(0.53) ; \epsilon(\mathrm{P}) 6800$. Intracellular DNA had $\mathbf{7 \cdot 2} \%$ phosphorus. Optical density ratios were: $250 / 260$ $(0 \cdot 87), 280 / 260(0.53) ; \epsilon(\mathrm{P}) 6800$.

The determination of RNA was prevented by a contaminant that interfered with the colour reaction, possibly a capsular polysaccharide (Webb, 1956) or polysugarphosphate (Zamenhof et al. 1953).

Staphylococcus (Micrococcus) epidermidis. A recently isolated strain of this coagulase-negative micro-organism which produced very little extracellular DNase activity (Weckman \& Catlin, 1957) was investigated also. Brain + heart infusion cultures, incubated for $42 \mathrm{hr}$. at $36^{\circ}$, were harvested and extracellular 
DNA was obtained as described (extracellular-1 of strain SA-B). Cellular lysis was more difficult to obtain, however. Concentrations of lysozyme and EDTA were doubled, the $\mathrm{pH}$ value raised to 9 , and the exposure (at $3^{\circ}$ ) was continued for 2 weeks. During this time the mixture became very thick and sticky, although some of the organisms may have remained intact. (Sodium dodecyl sulphate, $15 \%(w / v)$, did not induce lysis of this strain.) The liberated intracellular DNA was extracted, as described, and RNA was removed by alkali treatment. The extracellular DNA contained $2 \%$ RNA and $8.3 \%$ phosphorus. Optical density ratios were: 250/260 (0.85), 280/260 (0.56); $\epsilon(\mathrm{P})$ 6380. Base analyses are given in Table 1.

Pseudomonas fluorescens. A strain earlier designated as B (Catlin, 1956) was the source of DNA used in studies of DNase action reported in a later section. From this streptomycin-sensitive parent, a strain was derived for genetic study which was resistant to $1000 \mu \mathrm{g}$. dihydrostreptomycin sulphate/ ml.; this was a single-step mutant designated $B / S_{1000}$. DNA preparations from the mutant strain were obtained from $50 \mathrm{hr}$. cultures in brain-heart infusion incubated at $25^{\circ}$. Extracellular DNA was obtained by the previously described procedure with $0.2 \%(\mathrm{w} / \mathrm{v})$ sodium dodecyl sulphate. Many of the organisms retained motility during the entire exposure to detergent, indicating that the procedure caused little or no cellular destruction. Agar plates streaked with loopfuls of the mixture at the beginning and at the end of exposure showed qualitatively similar amounts of bacterial growth. Furthermore, the whole procedure for harvesting extracellular DNA was carried out with organisms which, beforehand, were subjected to DNase, were washed and resuspended in $\mathrm{NaCl}$-citrate solution. Failure to obtain fibres upon addition of ethanol showed that no appreciable release of DNA had been effected by the detergent treatment. Cellular lysis was produced, however, by application of $15 \%(\mathrm{w} / \mathrm{v})$ aqueous sodium dodecyl sulphate (Zamenhof, Reiner, De Giovanni \& Rich, 1956) and intracellular DNA was extracted from the lysate. Both DNA preparations were purified by two exposures to detergent (step 1, above) and to RNase, as follows. To $1 \mathrm{mg} . / \mathrm{ml}$. solutions in $0 \cdot 14 \mathrm{M}-\mathrm{NaCl}$, $0.1 \mathrm{mg}$. $/ \mathrm{ml}$. pancreatic RNase was added (Chargaff \& Zamenhof, 1948; Butler, Johns, Lucy \& Simson, 1956). The mixture was incubated at $25^{\circ}$ for $7 \mathbf{~ h r}$. with periodic addition of $0.01 \mathrm{~N}-\mathrm{NaOH}$ to maintain $\mathrm{pH} 6 \cdot 5-7 \cdot 5$. Thereafter, $0.02 \mathrm{~g} . / \mathrm{ml}$. of saline-washed Norit A (Zamenhof \& Chargaff, 1951) was added and, after storage at $0^{\circ}$ for $1 \mathrm{hr}$., was removed by centrifugation. The solution, made $2 \mathrm{M}$ with solid $\mathrm{NaCl}$, was dialysed against $2 \mathrm{M}-\mathrm{NaCl}$ (Butler et al. 1956) at $5^{\circ}$ for 5 days with frequent changes of the dialysing fluid. DNA was precipitated with 2 vol. of ethanol. The extracellular DNA preparation contained $10 \%$ RNA, 8.1\% phosphorus, and optical density ratios were: 250/260 (0.94), 280/260 (0.56). Values for intracellular DNA were: $9 \%$ RNA, 8.8\% phosphorus, 250/260 (0.93), 280/260 (0.55). Table 1 shows base analyses.

Alcaligenes faecalis. Cultures were incubated at about $25^{\circ}$ for $70 \mathrm{hr}$. (with continuous vigorous agitation during the first day) in a medium composed of proteose-peptone $\left(1 \%\right.$, w/v), yeast extract $\left(0.5 \%\right.$, w/v), with $\mathrm{K}_{2} \mathrm{HPO}_{4}$ solu- 
tion added aseptically to a concentration of $\mathbf{0 . 0 0 1}$ before inoculation. A crude extracellular-1 DNA preparation was obtained, and treated with alkali (see methods). After enzymic removal of extracellular DNA, organisms from which intracellular DNA was to be extracted were disintegrated in the Raytheon sonic oscillator (as described for enzymes). After centrifugation, the sediment was observed to be a soft pink layer and an underlying white adherent mass. The latter became highly viscous when stirred in $2 \mathrm{~m}-\mathrm{NaCl}$ solution. Fibres of nucleic acid were precipitated upon addition of 2 vol. of ethanol. This intracellular DNA, purified by steps $1-5$ (above), contained $7 \cdot 8 \%$ phosphorus. Optical density ratios were 250/260 (0.94), 280/260 (0.52); $\epsilon(\mathrm{P}) 7200$. Base analyses are shown in Table 1.

\section{Factors responsible for accumulation of extracellular $D N A$}

Staphylococcus aureus produces under certain conditions both slime-layer DNA and extracellular DNase. The DNase is unusual in being activated by calcium, instead of magnesium, having an optimum $\mathrm{pH}$ about $8 \cdot 6$, and being heat stable (Cunningham et al. 1956). High DNase activity is found extracellularly in brain-heart infusion cultures incubated at about $25^{\circ}$ with continuous strong agitation for $\mathbf{4 0 - 7 2} \mathrm{hr}$. (Weckman \& Catlin, 1957). Under these conditions polymerized DNA does not accumulate extracellularly. DNA in low yield has been obtained from the slimy masses of organisms harvested by centrifugation from $12-18 \mathrm{hr}$. unaerated brain-heart infusion cultures of three different strains of $S$. aureus. Considerably higher yields have been obtained from $36-48 \mathrm{hr}$. cultures in brain + heart infusion with $0 \cdot 8-$ $1 \cdot 0 \mathrm{M}-\mathrm{NaCl}$. This concentration of $\mathrm{NaCl}$ inhibited DNase activity; nevertheless, the enzyme was present as shown by tests carried out with dilutions of the supernatant culture fluid in the presence of calcium at $\mathrm{pH} \mathbf{8 . 5}$.

The presence of DNase was detected also in preparations of slime-layer DNA harvested from Staphylococcus aureus cultures. Extracted from the culture environment together with the DNA, the enzyme persisted through two steps of purification with sodium dodecyl sulphate and extraction of the DNA fibres with ethanol, with an intervening step with Cetrimide. One such preparation had 8 units DNase activity/mg. dried fibres; the supernatant medium from which the slimy organisms had been harvested contained 12,000 units $/ \mathrm{ml}$. No DNase activity was detected in a companion preparation of intracellular DNA extracted from the same culture. Subsequent steps of purification removed the associated DNase from the DNA.

A solution of DNA with associated DNase remained viscous for prolonged periods. Addition of calcium and $\mathrm{pH} 8.5$ buffer resulted in depolymerization. To investigate the influence of these factors on the accumulation of DNA-containing slime in cultures of Staphylococcus aureus, strain SA-B, brain + heart infusion was prepared with supplements as outlined in Table 2. Each of the four media was inoculated in quadruplicate; two sets were agitated vigorously (Weckman \& Catlin, 1957) during incubation, while the other two sets were unshaken. In spite of the buffers the $\mathrm{pH}$ value of shaken brain + heart infusion cultures tended to increase and the $\mathrm{pH}$ value of unshaken cultures tended to 


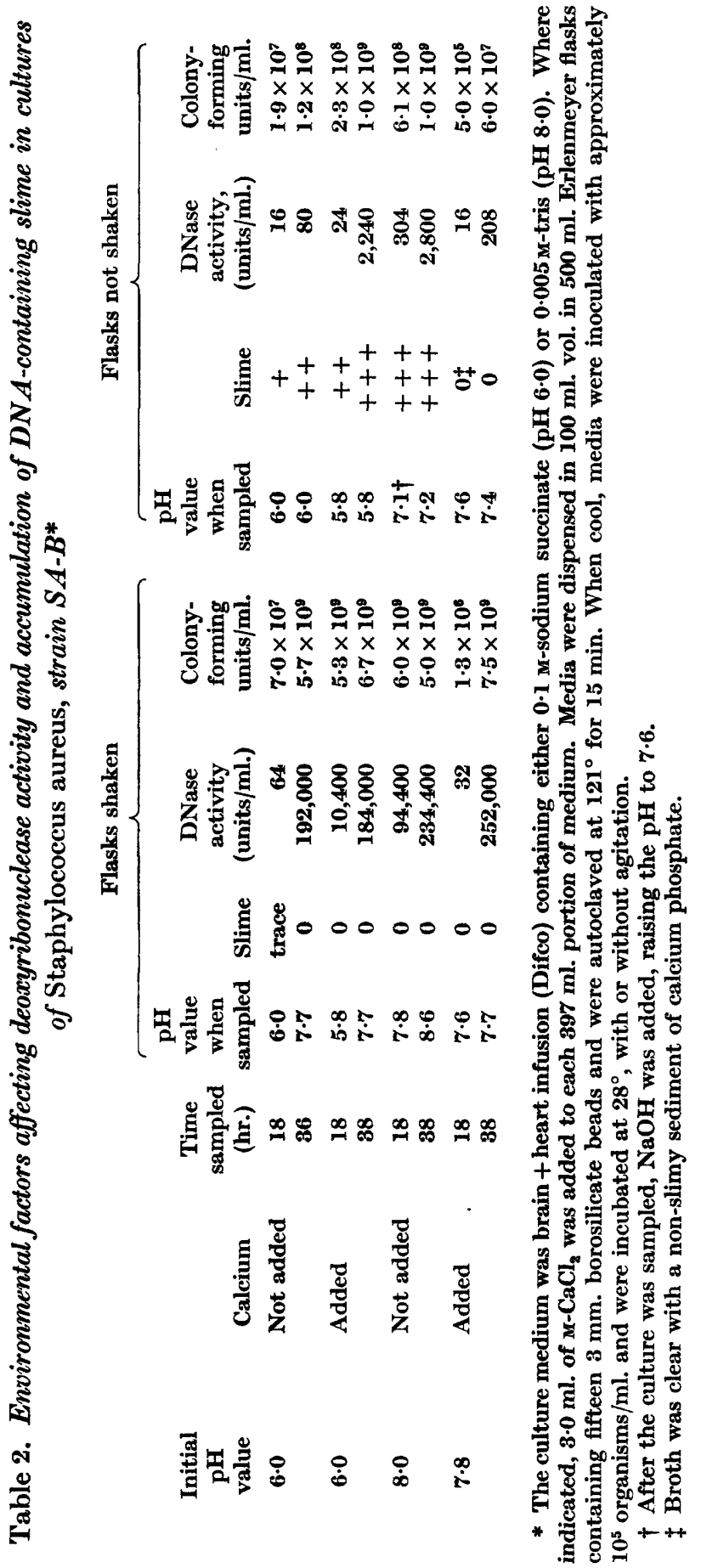


decrease during incubation. After incubation for $18 \mathrm{hr}$. one set of shaken cultures was sampled and immediately returned to the shaker. The duplicate set was allowed to stand for 1-2 hr. to permit aggregation and sedimentation of slime-covered organisms. A slimy sediment was observed only in the pH 6 broth without added calcium. Beginning at $36 \mathrm{hr}$., the flasks on the shaker were removed, sampled again, and allowed to stand; slime was not observed. During the intervening period of incubation, the two succinate media had become alkaline. An unshaken set of cultures was rotated before sampling at $18 \mathrm{hr}$, and at $38 \mathrm{hr}$. to disperse slimy masses of organisms with the aid of the beads. (Microscopic examination, howeven, showed more aggregation in unshaken than in shaken cultures.) The duplicate set of unshaken cultures was left undisturbed to permit observation of slime $(+++$ indicating the greatest amount). The morphology and Gram reaction of the cocci were generally typical in cultures having low $\mathrm{pH}$ values with added calcium and high $\mathrm{pH}$ values without added calcium, both shaken and unshaken. In other cultures the cocci tended to be enlarged, indicating that conditions were unfavourable; also, multiplication was retarded. (Numbers of colony-forming units/ml. were determined from averages of the numbers of colonies developing on triplicate brain + heart infusion agar plates spread with measured samples of a suitable dilution of culture, several dilutions being used in each case.)

Slime did not accumulate in the unshaken culture that had an alkaline $\mathrm{pH}$ value and added calcium. Lack of slime could not be attributed merely to insufficient multiplication, as indicated by similar results of a comparable test in which $1.5 \times 10^{8}$ colony-forming units $/ \mathrm{ml}$. were present after $44 \mathrm{hr}$. incubation. Slime accumulated in all other cultures, however, as shown in Table 2. Disappearance of these slimes could be brought about by increasing the $\mathrm{pH}$ value to 8 and/or adding calcium (or, as might be expected, by adding pancreatic DNase with magnesium). Shaken cultures apparently had a level of DNase high enough to prevent accumulation of slime, if either $\mathrm{pH}$ or calcium ion concentration was nearly optimum.

Pseudomonas fluorescens and Alcaligenes faecalis accumulate DNA-containing slime under a variety of culture conditions. Some depolymerizing activity against reference thymus DNA, 1-15 units/ml., was detected in cultures of both strains, occasionally even in the presence of DNA slime. In the case of $\boldsymbol{P}$. fluorescens, a ribonuclease-sensitive DNase inhibitor has previously been shown to be associated with extracellular DNA, protecting it from depolymerization (Catlin, 1956).

Characterization of the DNase of Alcaligenes faecalis was required before undertaking a study of the slime-layer DNA of this micro-organism. To obtain a more active source of enzyme, extracts of ultrasonic-disintegrated organisms were examined for DNase activity against reference thymus DNA. Moderate degrees of depolymerizing activity were found. The crude $A$. faecalis enzyme, which had been dialyzed against EDTA and water, was activated by a variety of cations. Listed in order of their decreasing activities as determined in viscometric tests at $37^{\circ}$ with thymus DNA $(1.0 \mathrm{mg} / \mathrm{ml}$. $)$ and tris buffer $(0.05 \mathrm{M}$; $\mathrm{pH} \mathrm{7.5)}$ these were: $\mathrm{CaCl}_{2}, \mathrm{CoCl}_{2}, \mathrm{MnCl}_{2}, \mathrm{MgCl}_{2}$ (all in final concentrations of 
$0.0025 \mathrm{M}), \mathrm{FeSO}_{4}(0.00025 \mathrm{M}), \mathrm{CuSO}_{4}$ and $\mathrm{ZnSO}_{4}(0.0005 \mathrm{M})$; the activity with zinc was only about $20 \%$ of that with calcium. With $\mathrm{CaCl}_{2}(0.005 \mathrm{M})$ and imidazole hydrochloride buffers $(0.05 \mathrm{M})$, the $A$. faecalis DNase was active over the whole range of $\mathrm{pH}$ values tested $(5 \cdot 2-9 \cdot 0)$. Optimum activity was found at $\mathrm{pH} 8 \cdot 0-8 \cdot 2$. Activity at $\mathrm{pH} 6 \cdot 0$ was $40 \%$ and, at $\mathrm{pH} 9 \cdot 0,60 \%$ of maximum. In exploratory tests comparable to those described with Staphylococcus aureus, addition of either calcium or cobalt to media did not perceptibly influence accumulation of $\boldsymbol{A}$. faecalis slime as compared with controls without added cation.

Masses of slime-covered cells, with a minimum of non-viscous broth, were aspirated from Alcaligenes faecalis cultures. Mixed with an equal quantity of buffer, this material was somewhat viscous and formed a rapidly sedimenting mass or web when a drop was allowed to fall into $90 \%(\mathrm{v} / \mathrm{v})$ acetone in water. Enzymic depolymerization of the slime-layer DNA was observed first by loss of viscosity, followed later by loss of web-forming capacity. The depolymerized slime when dropped into acetone immediately dispersed as a fine or flocculent precipitate. This occurred within 5 min. after adding pancreatic DNase $(0.01 \mathrm{mg} . / \mathrm{ml}$.). However, crude $A$. faecalis DNase, which depolymerized thymus DNA ( $1 \mathrm{mg}$. $/ \mathrm{ml}$.) within $3 \mathrm{hr}$., had no detectable effect upon the culture slime during 2 days of incubation. This same amount of A. faecalis DNase, together with pancreatic ribonuclease $(0.1 \mathrm{mg} . / \mathrm{ml}$.) depolymerized culture slime in $8 \mathrm{hr}$. Ribonuclease alone and trypsin $(0.5 \mathrm{mg} . /$ ml.) alone or mixed with $A$. faecalis DNase were without appreciable effect.

The significance of these findings was investigated in viscometric tests under conditions providing optimum nuclease activities. Activity of Alcaligenes faecalis DNase was routinely determined with reference thymus DNA (1 mg./ ml.) as substrate. Little activity was shown against other preparations, including DNA from Pseudomonas fluorescens, Staphylococcus aureus, and dog spleen, as well as from $A$. faecalis. (Inhibition of $\boldsymbol{P}$. fluorescens $\mathrm{DNase}$, on the other hand, was observed only with $P$. fluorescens DNA.). The action of pancreatic ribonuclease had suggested that a ribonucleic-acid inhibitor might be responsible for inactivity of the $A$. faecalis DNase. However, pretreatment of the DNA or the DNase preparations with ribonuclease effected only slight increases in DNase activity. No more than a doubling of activity was produced by concentrations of $10^{-1}-10^{-3} \mathrm{mg}$. ribonuclease $/ \mathrm{ml}$. An alternative explanation for the slight effect involved possible labilizing action by very small quantities of contaminating DNase, which were detected in this crystalline ribonuclease preparation, in confirmation of a previous observation (Zamenhof, 1957). This possibility was explored with DNA preparations extracted from dog spleen, $\boldsymbol{A}$. faecalis, and $\boldsymbol{P}$. fluorescens. The solution of DNA was incubated with a low concentration of pancreatic DNase, which resulted in a diminution of specific viscosity (5-25\%), but which did not prevent formation of a weblike fibrous precipitate in ethanol. Either directly after pancreatic DNase treatment or after an intervening step involving ethanol precipitation, the DNA was tested with $A$. faecalis DNase. Results comparable to those given in Table 3 were obtained with all three DNA preparations. The susceptibility 
to depolymerization by $\boldsymbol{A}$. faecalis DNase of a cautiously prepared, undried (Zamenhof, 1957) DNA was greatly increased by pretreatment with 10-7$10^{-8} \mathrm{mg}$. pancreatic DNase/ml. Crude thymus DNase also exerted a comparable labilizing effect. The relative resistance of an intact purified preparation of DNA to depolymerization by this DNase of $A$. faecalis suggests the explanation for the persistence of slime layer DNA. Thus far, a DNase having greater capacity to attack such DNA has not been detected in cultures of A. faecalis.

Table 3. Effect of pretreatment with pancreatic deoxyribonuclease on susceptibility of a deoxyribonucleic acid to the subsequent action of Alcaligenes faecalis deoxyribonuclease

\begin{tabular}{|c|c|c|c|}
\hline \multirow[b]{2}{*}{$\begin{array}{c}\text { DNA } \\
(1 \mathrm{mg} \cdot / \mathrm{ml} .) \\
\text { solution }\end{array}$} & \multirow[b]{2}{*}{$\begin{array}{c}\text { Pretreatment } \\
\text { with pancreatic } \\
\text { DNase (mg./ml.)* }\end{array}$} & \\
\hline & & $\begin{array}{c}\text { with added } \\
\text { A. faecalis } \\
\text { DNase }\end{array}$ & $\begin{array}{c}\text { without added } \\
\text { A. faecalis } \\
\text { DNase }\end{array}$ \\
\hline Thymus (reference) & 0 & $9 \cdot 9$ & - \\
\hline A. faecalis & 0 & 0.7 & - \\
\hline A. faecalis & $5 \times 10^{-8}$ & $9 \cdot 4$ & $0 \cdot 6 \ddagger$ \\
\hline A. faecalis & $1 \times 10^{-8}$ & $6 \cdot 2$ & $<0 \cdot 1 \ddagger$ \\
\hline
\end{tabular}

* Reaction at $37^{\circ}$ for $90 \mathrm{~min}$. with $\mathrm{MgCl}_{2}(0.025 \mathrm{M})$ in imidazole (pH 7.3) buffer. DNase activity of mixture with $5 \times 10^{-8} \mathrm{mg}$. $/ \mathrm{ml}$. pancreatic DNase was 2.2 units $/ \mathrm{ml}$.; reduction of viscosity $24 \%$ after $90 \mathrm{~min}$. reaction. Both pretreatment reactions terminated by addition of 2 vol. of ethanol. DNA precipitated as fibres; washed repeatedly in $95 \%(v / v)$ ethanol in water $(20 \mathrm{~min}$.$) and acetone (20 \mathrm{~min}$.$) , dried at 50^{\circ}$ for $90 \mathrm{~min}$., and dissolved in original volume of water.

$\dagger$ Reactions at $37^{\circ}$ with $\mathrm{CaCl}_{2}(0.005 \mathrm{M})$ in imidazole $\mathrm{pH} 8.0$ buffer.

$\ddagger$ Residual activity of pancreatic DNase.

The nature of the inhibition of Pseudomonas fluorescens DNase was studied. A preparation of $\boldsymbol{P}$. fluorescens (intracellular) DNA that had been deproteinized with two dodecyl sulphate treatments, but which contained $\mathbf{0 . 2 9} \mathbf{m g}$. RNA/mg. DNA, provided the source of DNase inhibitor. DNA (from dog spleen or from calf thymus) prepared in a manner to avoid dehydration (see methods) was found to be somewhat more susceptible than reference thymus DNA to attack by $P$. fluorescens DNase. Therefore, the DNase activity obtained using undried thymus DNA as substrate was designated $100 \%$. The DNase preparation, though somewhat purified, also contained some inhibitor (as shown by the inhibitor-destroying effect of ribonuclease; see Table 4), which was introduced into each test in a constant amount. The relationship between extent of enzyme inhibition and percentage of $P$. fluorescens DNA in various mixtures with thymus DNA is shown in Fig. 1. With increasing proportions of inhibitor-containing $\boldsymbol{P}$. fucoscens DNA, the percentage inhibition asymptotically approached a value somewhat below $100 \%$. The curve resembles that shown for the protein-type inhibitor of yeast DNase (Zamenhof \& Chargaff, 1949).

The DNase inhibitor of $\boldsymbol{P}$ seudomonas fluorescens was identified as a ribonucleic acid on the basis of its destruction by ribonuclease. To examine the possibility that the effect may have been due to DNase contaminating the crystalline 
$\mathbf{R N a s e}$ and to compare the results obtained using the DNases of $\boldsymbol{P}$. fluorescens and Alcaligenes faecalis, viscometric tests were carried out with DNA solutions which had been pretreated with either the RNase (boiled $10 \mathrm{~min}$. to destroy the DNase), or the DNase, of pancreas. The results shown in Table 4 indicate that DNase pretreatment of either $P$. fluorescens DNA or reference thymus DNA had little or no effect on the reaction of $\boldsymbol{P}$. fluorescens DNase,

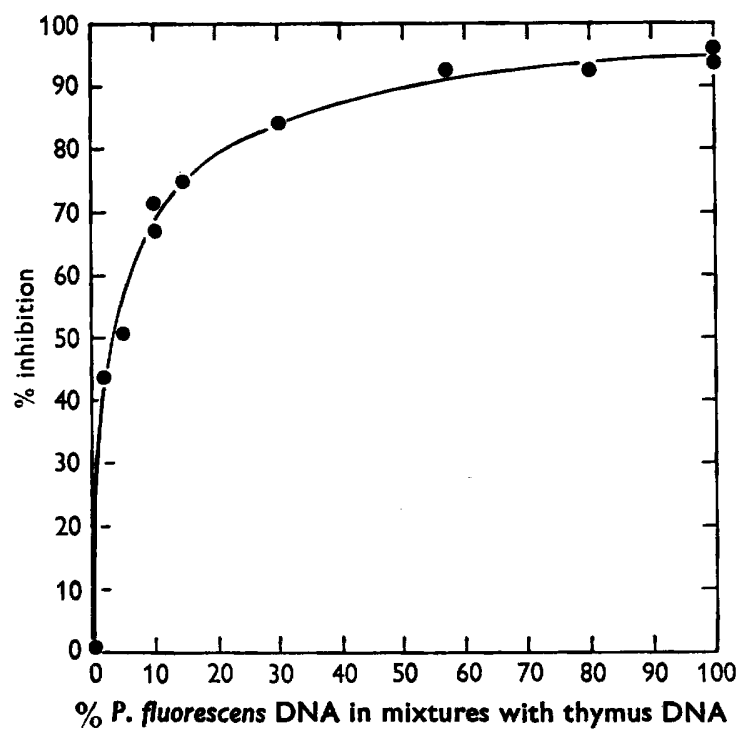

Fig. 1. \% Inhibition of Pseudomonas fluorescens deoxyribonuclease activity plotted against $\% P$. fluorescens DNA in mixtures with thymus DNA. Viscometric tests were carried out with solutions containing $1 \mathrm{mg}$. DNA/ml., $0.025 \mathrm{M}-\mathrm{MgCl}_{2}$, imidazole hydrochloride $(0.05 \mathrm{M}$ ) buffer $(\mathrm{pH} 7 \cdot 2)$, and $1 \mathrm{mg} . / \mathrm{ml}$. of a lyophilized, slightly purified DNase preparation obtained from a $7 \mathrm{hr}$. culture.

added thereafter; the slightly higher rates of reaction against treated DNA as compared with control DNA may be attributed to the continuing action of the pancreatic DNase. Preliminary ribonuclease treatment of DNA markedly increased the reaction rate of the $\boldsymbol{P}$. fluorescens $\mathrm{DNase}$. The increased activity against treated thymus DNA, as compared with untreated control, is due to the destruction of inhibitory $\mathrm{RNA}$ which contaminated the preparation of $\boldsymbol{P}$. fluorescens DNase.

The resistance of the preparation of undried Pseudomonas fluorescens DNA to attack by Alcaligenes faecalis DNase and the susceptibility of reference (dried) thymus DNA are shown in Table 4. The labilizing effect of DNase pretreatment on the more nearly 'native' preparation of DNA is revealed again. Pretreatment of either DNA with boiled RNase did not affect the subsequent rate of attack by the $A$. faecalis DNase. 


\section{DISCUSSION}

The analytical data obtained for the several extracellular bacterial DNA preparations indicate a general similarity of such material to DNA as found within bacterial and other cells. Representatives appear of both extremes (Chargaff, 1955) of the ratio, adenine + thymine: guanine + cytosine. The low phosphorus content of the detergent-treated preparations previously reported (Catlin, 1956) could be corrected to some extent by additional purification,

Table 4. Effects of pretreatment with pancreatic deoxyribonuclease or pancreatic ribonuclease on susceptibility of deoxyribonucleic acid preparations to the subsequent action of two bacterial deoxyribonucleases*

\begin{tabular}{|c|c|c|c|c|}
\hline & $\begin{array}{r}\text { Pseudomona } \\
\text { Dretre }\end{array}$ & $\begin{array}{l}\text { luorescens } \\
\text { nent }\end{array}$ & $\begin{array}{r}\text { Calf } \mathbf{t} \\
\text { DI } \\
\text { Pretre }\end{array}$ & mus \\
\hline & $\begin{array}{l}\text { Pancreatic } \\
\text { DNase } †\end{array}$ & Control & $\begin{array}{c}\text { Pancreatic } \\
\text { DNase }\end{array}$ & Control \\
\hline $\begin{array}{l}\text { Activity (units/ml.) after } \\
\text { addition of DNase from: }\end{array}$ & & & & \\
\hline Pseudomonas fluorescens & $3 \cdot 9$ & $2 \cdot 1$ & $9 \cdot 8$ & $8 \cdot 4$ \\
\hline Alcaligenes faecalis $\ddagger$ & $7 \cdot 4$ & $0 \cdot 1$ & $7 \cdot 9$ & $8 \cdot 9$ \\
\hline & Pretre: & aent & Pretre & nent \\
\hline & $\begin{array}{l}\text { Pancreatic } \\
\text { ribonuclease } \$\end{array}$ & Control & $\begin{array}{l}\text { Pancreatic } \\
\text { ribonuclease } 8\end{array}$ & Control \\
\hline $\begin{array}{l}\text { Activity (units/ml.) after } \\
\text { addition of DNase from: }\end{array}$ & & & & \\
\hline Pseudomonas fluorescens & $15 \cdot 1$ & $1 \cdot 9$ & $13 \cdot 1$ & $\mathbf{8 \cdot 9}$ \\
\hline Alcaligenes faecalis & $<0.1$ & $<0.1$ & $6 \cdot 5$ & $6 \cdot 8$ \\
\hline
\end{tabular}

* All incubations at $37^{\circ}$; all concentrations given are those in the actual reaction mixtures. Solutions were kept in an ice bath between pretreatment and subsequent assays. Controls were incubated in exactly the same manner as the enzymically pretreated preparations except for the absence of the crystalline enzyme. To eliminate effect of ageing of the bacterial DNase preparations, data in each horizontal line were obtained by simultaneous assays. One part of bacterial DNase solution was added to seven parts of pretreated DNA solution.

$\dagger$ Enzyme $\left(1.0 \times 10^{-7} \mathrm{mg} / \mathrm{ml}\right.$.) was allowed to act for $60 \mathrm{~min}$. in the presence of $0.1 \mathrm{M}$ imidazole- $\mathrm{HCl} \mathrm{pH} 7 \cdot 5$ and $0.02 \mathrm{M}-\mathrm{MgCl}_{2}$, resulting in $25 \%$ reduction in specific viscosity (2.8 units $/ \mathrm{ml}$. of DNase activity) of the thymus DNA (1 $\mathrm{mg} . / \mathrm{ml}$.); and $11 \%$ reduction in specific viscosity $(1.3 \mathrm{units} / \mathrm{ml}$.) of the $P$. fluorescens DNA (1 mg./ml.).

‡ Acting in the presence of $0.005 \mathrm{M}-\mathrm{CaCl}_{2}$.

$\$$ Enzyme (boiled $10 \mathrm{~min}$.) $5 \times 10^{-6} \mathrm{mg} \cdot / \mathrm{ml}$., DNA $2 \mathrm{mg} . / \mathrm{ml}$., NaCl 0.14 $\mathrm{M}, \mathrm{pH} 7,90 \mathrm{~min}$. incubation. Buffer-cation solutions were then added in equal volume. The $P$. fiuorescens DNase acted in the presence of $0.02 \mathrm{M}-\mathrm{MgCl}_{2}$ and $0.1 \mathrm{M}$-imidazole- $\mathrm{HCl} \mathrm{pH} 7.5 ; \mathrm{A}$. faecalis DNase in $0.005 \mathrm{M}-\mathrm{CaCl}_{2}, 0.1 \mathrm{~m}-$-imidazole- $\mathrm{HCl}, \mathrm{pH} \mathrm{8.0.}$

although the theoretical value was not attained. That part of the remaining impurity is polysaccharide (Jones, 1953) is suggested by the observation that even the best slime-layer DNA preparations show some caramelization on heating with acid. There may also be traces of impurity from the cetyltrimethylammonium bromide (Jones, Marsh \& Rizvi, 1957).

The consistent similarity of purine and pyrimidine content (Table 1) of the extracellular and intracellular preparations of DNA from each species 
indicates either an ultimate common source of the two or a similarity of mechanisms of synthesis. This result is obtained in spite of variations in preparative methods, with attendant variations in any possible fractionation of the material. Thus, analyses of DNA obtained directly from whole Staphylococcus aureus, strain $209 \mathrm{P}$, by a method similar to that used by Lee et al. (1956), agree not only with the data of these authors for this species (when calculated by the same method), but also with the base contents of the intracellular and extracellular DNA obtained from strain SA-B by detergent methods.

Similarity of composition of intracellular and extracellular DNA would be expected if the one were liberated by cellular disintegration to give rise to the other. Takahashi \& Gibbons (1957) explained in this way the formation of DNA-containing slime by the obligate halophile Micrococcus halodenitrificans, cultivated in a peptone medium containing suboptimal concentrations $(0.55-$ $0.65 \mathrm{M}$ ) of $\mathrm{NaCl}$. Under such conditions, these organisms apparently rupture at a rate which may approach, but does not equal, the rate of multiplication during the logarithmic growth phase. The possibility that one or another disruptive agent may operate in young ordinary cultures of various non-halophilic bacteria requires further investigation. The studies described here have elucidated three circumstances which permit the accumulation of highly polymerized extracellular DNA; however, the reason for its initial appearance remains obscure.

Possible biological consequences of the presence of extracellular DNA are now under investigation. The capacity of highly purified DNA (transforming principle) to convey genetic information is well established, although it cannot be assumed that all DNA has a specific genetic role (Hotchkiss, 1955). Several genetic effects can be conceived. One might be to effect heritable change in competent cells differing in one or more characters. (Indeed, preliminary experiments show that slime-layer DNA from Neisseria meningitidis possesses transforming capacity.) The possible occurrence in nature of DNA-conferred genetic change (lysate transformation) has been suggested by Hotchkiss (1951) on the basis of experiments with pneumococci. Addition of penicillin to a culture of a penicillin-sensitive type III strain resulted in lysis of the majority of cocci and liberation of DNA, which transformed penicillinresistant rough variants to type III capsule production. A second effect of extracellular DNA might be to protect organisms of the population from being transformed, by competing with DNA liberated from variants (see, for example, Hotchkiss, 1954; Lerman \& Tolmach, 1957). In this way slime-layer DNA might tend to stabilize the genetic structure of a population. In both these cases, partial depolymerization would result in loss of biological effectiveness. A less direct type of genetic effect, which would require depolymerization of the extracellular DNA, might result from possible selective action of the breakdown products (Braun, Firshein \& Whallon, 1957) on elements of a heterogeneous population. Possible non-genetic consequences of the presence of DNA-containing slime, likewise, must be considered, including protection against drying (Smithies \& Gibbons, 1955) or against radiation, deleterious 
effects of crowding, and action of the polyanionic nucleic acid as a selective barrier to the passage of cations (e.g. see Rogers, 1956).

An unexpected incidental finding of the present study was the specificity of the Alcaligenes faecalis DNase for substrate which had been exposed to some form of degradation so mild as to leave the viscosity essentially unchanged. The most susceptible substrate yet used is the reference thymus DNA, which has been stored for several years at room temperature in the form of dry fibres. Cautiously prepared samples of DNA, including one having transforming activity (Haemophilus influenzae), are far more resistant to attack by A. faecalis DNase. This enzyme may prove a useful tool to indicate slight degradation of DNA structure associated with loss of the 'native state'.

This investigation was supported by research grants C-2405 and C-2128 from the National Institutes of Health, U.S. Public Health Service.

\section{REFERENCES}

Braun, W., Frrshein, W. \& Whatlon, J. (1957). Effects of desoxyribonucleic acid breakdown products on bacterial population changes and virulence. Science, 125, 445 .

Butler, J. A. V., Johns, E. W., Lucy, J. A. \& Simson, P. (1956). The composition of nucleic acids prepared from rat and mouse tumours. Brit. J. Cancer, 10, 202.

Caturn, B. W. (1956). Extracellular deoxyribonucleic acid of bacteria and a deoxyribonuclease inhibitor. Science, 124, 441.

Chargaff, E. (1955). Isolation and composition of the deoxypentose nucleic acids and of the corresponding nucleoproteins. In The Nucleic Acids, vol. I. New York: Academic Press Inc.

Chargaff, E. \& Zamenhof, S. (1948). The isolation of highly polymerized desoxypentosenucleic acid from yeast cells. J. biol. Chem. 173, $32 \%$.

Cohen, S. S. (1947). Streptomycin and desoxyribonuclease in the study of variations in the properties of a bacterial virus. J. biol. Chem. 168, 511.

Cunningham, L., Catlin, B. W. \& Privat de Garilhe, M. (1956). A deoxyribonuclease of Micrococcus pyogenes. J. Amer. chem. Soc. 78, 4642.

Di sCHE, Z. (1955). Color reactions of nucleic acid components. In The Nucleic Acids, vol. I. New York: Academic Press Inc.

DutTa, S. K., Jones, A. S. \& Stacey, M. (1953). The separation of desoxypentosenucleic acids and pentosenucleic acids. Biochim. biophys. Acta, 10, 613.

Fiske, C. H. \& Subbarow, Y. (1925). The colorimetric determination of phosphorus. J. biol. Chem. 66, 375.

Hoтchkiss, R. D. (1948). The quantitative separation of purines, pyrimidines, and nucleosides by paper chromatography. J. biol. Chem. 175, 315.

Horchkiss, R. D. (1951). Transfer of penicillin resistance in pneumococci by the desoxyribonucleate derived from resistant cultures. Cold. Spr. Harb. Symp. quant. Biol. 16, 457.

Hotchkiss, R. D. (1954). Cyclical behavior in pneumococcal growth and transformability occasioned by environmental changes. Proc. nat. Acad. Sci., Wash. 40, 49.

Hotchiriss, R. D. (1955). The biological role of the deoxypentose nucleic acids. In The Nucleic Acids, vol. Ir, p. 469. New York: Academic Press Inc.

Jornson, E. A. (1955). Unpublished work cited pp. 502-503 in The Nucleic Acids, vol. I. New York: Academic Press Inc.

JoNEs, A. S. (1953). The isolation of bacterial nucleic acids using cetyltrimethylammonium bromide (Cetavlon). Biochim. biophys. Acta, 10, 607. 
Jones, A. S., MarSH, G. E. \& Rizvi, S. B. H. (1957). The isolation and composition of the nucleic acids of Aerobacter aerogenes. J. gen. Microbiol. 17, 586.

KAY, D. (1954). The deoxyribonuclease of typhoid bacilli and its effect on typhoid bacteriophage nucleic acid. J. gen. Microbiol. 11, 45.

Kay, E. R. M., Simmons, N. S. \& Dounce, A. L. (1952). An improved preparation of sodium desoxyribonucleate. J. Amer. chem. Soc. 74, 1724.

KING, E. J. (1932). The colorimetric determination of phosphorus. Biochem. J. 26, 292.

Korkes, S., del Campillo, A., Gunsalus, I. C. \& Ochoa, S. (1951). Enzymatic synthesis of citric acid. IV. Pyruvate as acetyl donor. J. biol. Chem. 193, 721.

LEE, K. Y., WAHL, R. \& BARBU, E. (1956). Contenu en bases puriques et pyrimidiques des acides désoxyribonucléiques des bactéries. Ann. Inst. Pasteur, 91, 212.

Lerman, L. S. \& Tolmach, L. J. (1957). Genetic transformation. I. Cellular incorporation of DNA accompanying transformation in pneumococcus. Biochim. biophys. Acta, 26, 68.

McCanTy, M. (1948). The occurrence of nucleases in culture filtrates of group A hemolytic streptococci. J. exp. Med. 88, 181.

McCar'Ty, M. \& Avery, O. T. (1946). Studies on the chemical nature of the substance inducing transformation of pneumococcal types. III. An improved method for the isolation of the transforming substance and its application to pneumococcus types II, III, and VI. J. exp. Med. 83, 97.

Masui, M., Honda, Y., Hikita, K., Iwata, T., Pan, I-H. \& Taki, I. (1956). Nucleodepolymerases. I. Occurrence of ribonuclease and deoxyribonuclease in culture filtrates of various bacteria. Osaka City Med. J. 2, 141. In Chem. Abstracts 52, 6486 (1958).

Mauzy, W., Braun, W. \& Whallon, J. (1955). Studies on DNA and DNase in Brucella cultures. Bact. Proc. p. 46.

OAKLEY, C. L. \& WARrack, G. H. (1951). The ACRA test as a means of estimating hyaluronidase, deoxyribonuclease and their antibodies. J. Path. Bact. 63, 45 .

REPASKe, R. (1956). Lysis of Gram-negative bacteria by lysozyme. Biochim. biophys. Acta, 22, 189.

Rogers, H. J. (1956). The formation of extracellular enzymes by staphylococci. Ann. N.Y. Acad. Sci. 65, 132.

Shugar, D. \& Fox, J. J. (1952). Spectrophotometric studies of nucleic acid derivatives and related compounds as a function of $\mathrm{pH}$. I. Pyrimidines. Biochim. biophys. Acta, 9, 199.

Smith, J. D. \& Wyatt, G. R. (1951). The composition of some microbial deoxypentose nucleic acids. Biochem. J. 49, 144.

Smrthies, W. R. \& Gibbons, N. E. (1955). The deoxyribose nucleic acid slime layer of some halophilic bacteria. Canad. J. Microbiol. 1, 614.

TAKahashi, I. \& Gibbons, N. E. (1957). Effect of salt concentration on the extracellular nucleic acids of Micrococcus halodenitrificans. Canad. J. Microbiol. 3, 687.

Warrack, G. H., Bidwell, E. \& OAKLey, C. L. (1951). The beta-toxin (deoxyribonuclease) of Cl. septicum. J. Path. Bact. 63, 293.

WeBB, J. M. (1956). A sensitive method for the determination of ribonucleic acid in tissues and microorganisms. J. biol. Chem. 221, 635.

Weckman, B. G. \& Catrin, B. W. (1957). Deoxyribonuclease activity of micrococci from clinical sources. J. Bact. 73, 747.

WYatT, G. R. (1951). The purine and pyrimidine composition of deoxypentosenucleic acids. Biochem. J. 48, 584.

Wyatt, G. R. \& Cohen, S. S. (1953). The bases of the nucleic acids of some bacterial and animal viruses: the occurrence of 5-hydroxymethylcytosine. Biochem. $J$. 55,774 . 
Zamenhof, S. (1957). Properties of transforming principles. Also, discussion, p. 386. Symposium: The Chemical Basis of Heredity. Baltimore: The Johns Hopkins Press.

Zamenhof, S., Alexander, H. E. \& Leidy, G. (1953). Studies on the chemistry of the transforming activity. I. Resistance to physical and chemical agents. J. exp. Med. 98, 373.

Zamenhof, S., Brawerman, G. \& Chargaff, E. (1952). On the desoxypentose nucleic acids from several microorganisms. Biochim. biophys. Acta, 9, 402.

Zamenhof, S. \& Chargaff, E. (1949). Studies on the desoxypentose nuclease of yeast and its specific cellular regulation. J. biol. Chem. 180, 727 .

Zamenhof, S. \& ChargafF, E. (1951). Separation of deoxypentose and pentose nucleic acids. Nature, Lond. 168, 604.

Zamenhof, S., Leidy, G., Fitzgerald, P. L., Alexander, H. E. \& Chargaff, E. (1953). Polyribophosphate, the type-specific substance of Hemophilus influenzae, type b. J. biol. Chem. 203, 695.

Zamenhof, S., Reiner, B., De Giovanni, R. \& Rich, K. (1956). Introduction of unnatural pyrimidines into deoxyribonucleic acid of Escherichia coli. J. biol. Chem. 219, 165.

(Received 4 June 1958) 